УДК 332.14

DOI 10.18101/2304-4446-2019-1-62-67

\title{
УНИВЕРСИТЕТЫ КАК ИНСТИТУТЫ РЕГИОНАЛЬНОГО РАЗВИТИЯ НА ПРИМЕРЕ РЕСПУБЛИКИ БУРЯТИЯ
}

\section{(C) Янтранов Александр Евгеньевич}

кандидат экономических наук, заведующий лабораторией региональной экономики, Бурятский государственный университет

Россия, 670000, г. Улан-Удэ, ул. Смолина, 24а

E-mail: yantran@mail.ru

\section{(ㄱ) Атанов Николай Иванович}

доктор экономических наук, ведущий научный сотрудник, Бурятский государственный университет

Россия, 670000, г. Улан-Удэ, ул. Смолина, 24а

E-mail: atanov44@yandex.ru

\section{(C) Архипов Сергей Валерьевич}

кандидат технических наук, доцент кафедры информационных технологий, Бурятский государственный университет

Россия, 670000, г. Улан-Удэ, ул. Смолина, 24a

E-mail: svarkh@mail.ru

Региональные университеты претендуют на статус точек роста территорий за счет интеграционных проектов развития на основе взаимодействия власти, бизнеса и местных сообществ. При этом университеты начинают играть более активную роль и в международных отношениях в качестве инструмента «мягкой силы», в инновационном развитии и других сферах.

Региональные вузы должны стать центрами консолидации усилий разных сторон социально-экономического развития территорий, совершенствовать инновационную инфраструктуру, участвовать в улучшении социальной сферы региона, в международных отношениях в качестве институтов «мягкой силы», институтами развития «зеленой» экономики и устойчивого развития.

В статье систематизирована информация по теме и представлено видение развития университетов как институтов развития региона на примере Республики Бурятия, чья деятельность направлена на плодотворное взаимодействие с региональными стейкхолдерами и активизацию устойчивого социально-экономического роста региона.

Ключевые слова: стратегия развития; региональные институты развития; региональная экономика; университеты; высшее образование; устойчивое развитие.

\section{Для цитирования:}

Янтранов А. Е., Атанов Н. И., Архипов С. В. Университеты как институты регионального развития на примере Республики Бурятия // Вестник Бурятского государственного университета. Экономика и менеджмент. 2019. Вып. 1. С. 62-67.

Введение. Традиционное представление о роли высших учебных заведений в региональном развитии складывается исходя из их вклада в формирование кадрового и научно-инновационного потенциала региона. Система высшего образования обеспечивает подготовку высококвалифицированных кадров, востребованных прежде всего региональным рынком труда как в экономической, так и в 
Янтранов А. Е., Атанов Н. И., Архипов С. В. Университеты как институты регионального развития на примере Республики Бурятия

социальной сфере. Научно-инновационная составляющая системы высшего образования не только определяет выполнение фундаментальных и прикладных исследований, но и обеспечивает коммерциализацию результатов научных исследований и содействует модернизации экономической и социальной сферы региона.

Однако в современных реалиях регионального развития необходимо учитывать роль университетов в более широком плане, в котором региональные университеты должны быть представлены как точки роста региона за счет интеграционных проектов развития на основе взаимодействия региональной власти, региональных и муниципальных образовательных организаций и бизнес-структур.

Функции университетов. Роль университетов может быть представлена следующим образом [2, с. 31].

Во-первых, региональные вузы должны стать центрами консолидации усилий по выстраиванию моделей долгосрочного взаимодействия с основными стейкхолдерами - потенциальными клиентами образовательных услуг. Для успешной реализации этой роли жизненно важным становится формирование общеобразовательной платформы с участием школ, средних специальных образовательных учреждений, университетов и работодателей, обеспечивающей талантливую молодежь необходимыми ресурсами и возможностями для самореализации на всех стадиях их развития. Также необходимо обеспечить доступ населения всех возрастов к непрерывному качественному образованию всех уровней.

Одним из вызовов для Республики Бурятия является проблема миграционного оттока активной молодежи из региона. Порядка 1/3 выпускников школ ежегодно выезжает из Республики Бурятия для поступления в вузы других регионов, с которыми связывают продолжение своей карьеры. В противовес отрицательной тенденции региональные вузы в своей деятельности должны создавать опережающие и практико-ориентированные образовательные программы, связывая проекты социально-экономического развития региона с системой ранней профориентации школьников и дошкольников. Чем больше продуктивного сетевого взаимодействия молодежи будет с активными субъектами региона на базе университетов, тем выше вероятность продолжения их обучения в местных вузах и связывания их карьеры с регионом.

Во-вторых, развитие научного и инновационного потенциала региона на базе инновационной инфраструктуры региональных вузов за счет интеграции совместных усилий власти, бизнес-структур и университетов [3, с.78]. В настоящее время основной проблемой реализации этой роли для научно-образовательных учреждений является ограниченное количество потенциальных крупных заказчиков, которые предъявляли бы спрос на исследования и разработки внутри Республики Бурятия.

Для преодоления этой проблемы региональные университеты должны напрямую выстраивать инфраструктуру развития малого инновационного предпринимательства, выступая уже в роли институтов коммерциализации технологических разработок, поддерживая развитие компаний на всех стадиях их роста и обеспечивая их взаимодействие с федеральными и международными институтами развития.

Университетам необходимо учитывать, что стратегией социальноэкономического развития Республика Бурятия до 2025 г. на средне- и долгосроч- 
ную перспективу к числу ключевых направлений экономики отнесены минерально-сырьевой комплекс, туристско-рекреационный комплекс, агропромышленный комплекс, лесопромышленный комплекс, инновационная деятельность, развитие человеческого потенциала ${ }^{1}$. Так, например, в системе здравоохранения Республики Бурятия актуальным направлением развития является интегративная медицина, базирующаяся на методиках классической западной и традиционной восточной медицины. В перспективе бурятская медицина претендует на роль моста между европейской и азиатской медициной и фармацевтикой, что отражено в действующих программных документах социально-экономического развития региона ${ }^{2}$ и проекте Стратегии социально-экономического развития Республики Бурятия до 2035 года.

Интеграцию научной, учебной, практической медицины по оси Улан-Удэ (РФ) - Улан-Батор (Монголия) - Хух-Хото (КНР) следует включить в перечень пилотных проектов в трехстрановой программе создания экономического коридора Китай - Монголия - Россия. Роль региональных вузов, в первую очередь Бурятского государственного университета, связана с развитием научноинновационного потенциала университета, консолидирующего ресурсы региональных вузов, научных институтов и предприятий региона, ориентированного на удовлетворение актуальных потребностей устойчивого развития в области биомедицинских, когнитивных и информационных технологий.

В-третьих, участие региональных вузов в развитии социальной сферы региона. Неотъемлемой составляющей региональных вузов является кадровое обеспечение региона квалифицированными кадрами социальной сферы. Региональные вузы осуществляют подготовку кадров по социально значимым и приоритетным направлениям для нужд региона, тем самым обеспечивают привлекательность региона для комфортного проживания. Так же роль региональных вузов в социальной политике регионе представлена в поддержке социальных проектов помощи талантливой молодежи, в обеспечении открытого доступа к знаниям, в развитии гражданского общества и популяризации спорта, культуры и местных традиций и др.

Реализация данной роли университетами региона предусматривает активное взаимодействие с местными сообществами по совершенствованию образовательной, социокультурной, пространственной среды города и региона, т. е. формирование определенной региональной «экосистемы» - открытой площадки для взаимодействия образовательных учреждений с общественными структурами, бизнес-сообществами, органами государственной власти с целью решения социальных и экологических проблем региона, продвижения и внедрения общественных, практико-ориентированных проектов [2, с. 134]. Университеты активно участвуют в общественной жизни региона: организуя спортивные, культур-

\footnotetext{
${ }^{1}$ О стратегии социально-экономического развития Республики Бурятия до 2025 года: постановление Правительства Республики Бурятия от 15 декабря 2007 г. № 410. URL: http://docs.cntd.ru/document/446260821 (дата обращения: 20.11.2018).

${ }^{2} \mathrm{O}$ программе социально-экономического развития Республики Бурятия на период до 2020 года: закон Республики Бурятии, утвержденный в форме республиканского закона №1903-IV от 14.03.2011 г. URL: http://docs.cntd.ru/document/ 895292263 (дата обращения: 20.11.2018).
} 
Янтранов А. Е., Атанов Н. И., Архипов С. В. Университеты как институты регионального развития на примере Республики Бурятия

ные и общественно-значимые мероприятия, в т. ч. предоставляя свои ресурсы и вовлекая студентов и профессорско-преподавательский состав.

В-четвертых, участие региональных вузов в международной сфере в качестве институтов «мягкой силы». Республика Бурятия в силу естественноисторических причин может быть провайдером восточно-азиатской политики России в качестве «мягкой» силы. В пользу реальности проекта говорит тот факт, что Бурятия - самая восточная азиатская автономия России, являющаяся северным конечным ареалом всего буддийского мира. В республике действует Институт монголоведения, буддологии и тибетологии СО РАН, в Бурятском государственном университете - Восточный институт, филиал Института Конфуция (Китай) и Институт имени короля Сечжона (Республика Корея) [1, с. 4].

История продвижения внешней политики России на монгольском, китайском, тибетском, индийском направлениях в XIX - начале XX века свидетельствует об активном участии бурятских исследователей - Агвана Доржиева, Гомбожапа Цыбикова, братьев Бадмаевых, Цэвэна Жамсарано, Эрдэни Батухана, ЭлбэгДоржи Ринчино, Матвея Амагаева, Михаила Богданова и многих других деятелей, добившихся впечатляющих результатов в Азиатской внешней политике Царской России и молодой Советской республики.

Активизация в первую очередь культурных, образовательных, спортивных, научных, конфессиональных обменов, развитие въездного туризма из стран, определение г. Улан-Удэ в качестве международной публичной площадки для проведения встреч, саммитов, форумов ШОС, АТЭС, ЕАЭС, АТЗСТ, ТТП и других международных мероприятий должны осуществляться с учетом важнейшей роли университетов и научных учреждений региона.

B-пятых, активное участие в повышении экологической сознательности граждан и сопровождение реализации экологической политики в Байкальском регионе, развитие модели устойчивого развития в разных форматах. Это и прямое участие университетов в экологических акциях, пропаганде «зеленого» развития, экспертно-аналитическое сопровождение органов власти по разным аспектам экологических проблем, развитие соответствующих образовательных программ разного уровня, обеспечение развития «зеленых» инноваций и многое другое. В связи с негативными изменениями в экосистеме озера Байкал развитие функции университетов в этом сегменте приобретает высокую значимость.

Выводы и противоречия. Реализация направлений деятельности научнообразовательных учреждений станет серьезным вкладом в развитие региона. При этом стратегическое развитие регионального университета требует комплексного подхода, который бы учитывал текущие и будущие результаты воздействия университета на территорию своей локализации, которые не являются очевидными на первый взгляд и создают явное противоречие.

Противоречие стратегического развития заключается в следующем: если региональный университет будет ориентироваться исключительно на текущие потребности региона, находящегося на периферии, он рискует еще больше отстать от международного уровня, а если будут взяты ориентиры на современные глобальные научные и образовательные стандарты, университет рискует стать менее адекватным текущим потребностям региона.

Совмещение и реализация двух векторов развития - одновременное участие в развитии региона и формирование университета мирового класса (как реализация 


\section{ВЕСТНИК БУРЯТСКОГО ГОСУДАРСТВЕННОГО УНИВЕРСИТЕТА ЭКОНОМИКА И МЕНЕДЖМЕНТ}

геополитического интереса России в Центрально-Азиатском макрорегионе) - являются стратегическим вызовом не только для местной системы высшего образования, но и для ключевых субъектов социально-экономического развития региона: крупного регионального бизнеса, предъявляющего спрос на кадры соответствующего уровня, региональной власти, координирующей формирование государственного заказа на подготовку кадров и оказывающей поддержку инвестиционной деятельности, существенно влияющей на рынок труда в будущем ${ }^{1}$.

Статья выполнена в рамках грантовой поддержки Бурятского государственного университета

\section{Литература}

1. Атанов Н. И., Абаев Н. В. Концептуально-методологические и научнообразовательные компоненты успеха евразийского экономического сотрудничества // Вестник Бурятского государственного университета. Экономика и менеджмент. 2017. № 2. C. 3-6.

2. Перфильева О. В. Университет и регион: на пути к реализации третьей функции // Вестник международных организаций. 2011. № 1(32). С. 133-144.

3. Университет и регион. Выбор институциональной стратегии развития СевероВосточного федерального университета им. М. К. Аммосова с учетом потребностей территории Дальнего Востока: кол. моногр. /под науч. ред. М. В. Ларионовой, Е. И. Михайловой, О. В. Перфильевой. М.: Логос, 2013. 308 с.

4. Янтранов А. Е. Вопросы изменения институциональной среды для развития предпринимательства в Республике Бурятия // Вестник Бурятского государственного университета. 2015. № 2-2. С. 75-79.

\section{UNIVERSITIES AS INSTITUTIONS OF REGIONAL DEVELOPMENT: \\ THE CASE OF THE REPUBLIC OF BURYATIA}

\section{Aleksandr E. Yantranov}

Cand. Sci. (Econ.), Head of Regional Economics Laboratory,

Buryat State University

24a Smolina St., Ulan-Ude 670000, Russia

E-mail: yantran@mail.ru

\section{Nikolay I. Atanov}

Dr. Sci. (Econ.), Leading Researcher,

Buryat State University

24a Smolina St., Ulan-Ude 670000, Russia

E-mail: atanov44@yandex.ru

Sergey V. Arkhipov

Cand. Sci. (Engineering), A/Prof. of Information Technologies Department

Buryat State University

24a Smolina St., Ulan-Ude 670000, Russia

E-mail: svarkh@mail.ru

1 Программа развития ФГБОУ ВО "Бурятский государственный университет" на 2016-2020 гг. URL: http://www.bsu.ru/content/page/16/programma-razvitiya-fgbou-voburyatskii-gosudarstvennii-universitet.pdf (дата обращения: 20.11.2018). 
Янтранов А. Е., Атанов Н. И., Архипов С. В. Университеты как институты регионального развития на примере Республики Бурятия

Regional universities claim to be growth zones of territories by means of integration development projects based on the interaction of government, business and local communities. At the same time, universities are beginning to play more active role in international relations as a tool of "soft power" in innovative development and other areas.

Regional universities should become centers for consolidation of the efforts of different sides of regional socio-economic development, improve innovation infrastructure, participate in the course of regional social policy, international relations as institutions of "soft power", and follow a policy of green economy and sustainable development.

The article presents the vision of the development of universities as regional institutions in the case of the Republic of Buryatia, which activities are aimed at fruitful interaction with regional stakeholders and sustainable socio-economic growth in the region.

Keywords: development strategy; regional development institutions; regional economy; universities; higher education; sustainable development. 